\title{
Detection of Hemotropic Mycoplasma sp. in white-eared opossums (Didelphis albiventris) from Southern Brazil
}

Detecção de Mycoplasma sp. hemotrópico em gambás-de-orelha-branca (Didelphis albiventris) no Sul do Brasil

\author{
Paula Fernanda Massini ${ }^{1}$; Ricardo Nascimento Drozino²; Flávio Haragushiku Otomura ${ }^{3}$; \\ Anna Claudia Baumel Mongruel ${ }^{4}$; Jessica Damiana Marinho Valente ${ }^{4}$; Max Jean de Ornelas Toledo²; \\ Thiago Fernandes Martins ${ }^{5}$; Odilon Vidotto; Thállitha Samih Wischral Jaime Vieira \\ Rafael Felipe da Costa Vieira** (1)
}

\begin{abstract}
${ }^{1}$ Departamento de Medicina Veterinária Preventiva, Universidade Estadual de Londrina - UEL, Londrina, PR, Brasil
${ }^{2}$ Departamento de Ciências Biológicas, Universidade Estadual de Maringá - UEM, Maringá, PR, Brasil

${ }^{3}$ Departamento de Ciências Biológicas, Universidade Estadual do Norte do Paraná - UENP, Bandeirantes, PR, Brasil

${ }^{4}$ Departamento de Medicina Veterinária, Universidade Federal do Paraná - UFPR, Curitiba, PR, Brasil

${ }_{5}^{5}$ Departamento de Medicina Veterinária Preventiva e Saúde Animal, Faculdade de Medicina Veterinária, Universidade de São Paulo USP, São Paulo, SP, Brasil
\end{abstract}

Received May 24, 2019

Accepted June 26, 2019

\begin{abstract}
Opossums are marsupials from the New World of the genus Didelphis and known as synanthropic animals due to their proximity with human beings. To date, 'Candidatus Mycoplasma haemodidelphis' has been solely found infecting the North American opossum (Didelphis virginiana). Accordingly, the aim of this study was to screen eight white-eared opossums (Didelphis albiventris) from a public park in Maringa city, Paraná State, southern Brazil, for hemoplasma infection. Blood samples were taken from caudal venipuncture, and DNA was extracted and further screened by a pan-hemoplasma PCR assay. Seven out of eight (87.50\%; CI 95\%: 47.35-99.68\%) white-eared opossums were positive for Mycoplasma spp. Sequencing of the $16 \mathrm{~S}$ rRNA fragment showed $98,97 \%$ identity with ' $\mathrm{Ca}$. M. haemodidelphis' detected in the USA. Three out of eight (37.50\%; CI 95\%: 8.52-75.51\%) white-eared opossums were infested by Amblyomma dubitatum ticks. This is the first report on detection of a potentially novel hemotropic Mycoplasma sp. infecting opossums from South America.
\end{abstract}

Keywords: Marsupials, hemotropic mycoplasmas, hemoplasmas, Mycoplasma sp.

\section{Resumo}

Gambás são marsupiais do Novo Mundo, pertencentes ao gênero Didelphis, e considerados animais sinantrópicos devido à sua proximidade com seres humanos. Atualmente, a espécie 'Candidatus Mycoplasma haemodidelphis' só foi encontrada infectando gambá norte americano (Didelphis virginiana). O objetivo do presente estudo foi detectar a infecção por hemoplasmas em oito gambás-de-orelha-branca (Didelphis albiventris) capturados em um parque público da cidade de Maringá, no Estado do Paraná, sul do Brasil. Amostras de sangue foram coletadas por venopunção caudal para a extração do DNA e posterior análise pela PCR para espécies de hemoplasmas. Sete de oito animais $(87,50 \%$; CI 95\%: 47,35-99,68\%) foram considerados positivos para Mycoplasma spp. O sequenciamento do fragmento do gene 16 rRNA obtido apresentou $98.97 \%$ de similaridade com sequências de ' $\mathrm{C} a$. M. haemodidelphis' detectadas nos Estados Unidos. Três gambás (37,50\%; CI 95\%: 8,52-75,51\%) estavam infestados por carrapatos da espécie Amblyomma dubitatum. Esse é o primeiro relato de detecção de uma potencial nova espécie de Mycoplasma hemotrópico infectando gambás na América do Sul.

Palavras-chave: Marsupiais, micoplasmas hemotrópicos, hemoplasmas, Mycoplasma sp.

*Corresponding author: Rafael Felipe da Costa Vieira. Departamento de Medicina Veterinária, Campus Agrárias, Universidade Federal do Paraná UFPR, R. dos Funcionários, 1540, Juvevê, CEP 80035-050, Curitiba, PR, Brasil.e-mail: rvieira@ufpr.br 
Hemotropic mycoplasmas (hemoplasmas) are small pleomorphic bacteria that may cause immune-mediated hemolytic anemia in animals and human beings (MESSICK, 2004; SYKES et al., 2010). Mycoplasma sp. have been detected in wildlife worldwide (MESSICK, 2004; VOLOKHOV et al., 2017). In Brazil, hemoplasma species have been found in wildlife, such as lion (Panthera leo) (GUIMARAES et al., 2007), capybaras (Hydrochaeris hydrochaeris) (VIEIRA et al., 2009), small rodents (GONÇALVES et al., 2015; SOUSA et al., 2017), nonhuman primates (BONATO et al., 2015; CUBILLA et al., 2017b; RAMALHO et al., 2017; de MELO et al., 2019), coatis (Nasua nasua) (CUBILLA et al., 2017a; SOUSA et al., 2017), wild canids (ANDRÉ et al., 2011; de SOUSA et al., 2017), free-ranging and/or captive jaguars (Panthera onca) (ANDRÉ et al., 2011; FURTADO et al., 2018), pumas (Puma concolor), jaguarundis (Puma yagouaroundi), little spotted cats (Leopardus tigrinus) (ANDRÉ et al., 2011), ocelots (Leopardus pardalis) (ANDRÉ et al., 2011; SOUSA et al., 2017), bats (IKEDA et al., 2017) and wild boars (DIAS et al., 2019).

Opossums are marsupials comprised on the genus Didelphis, recognized as synanthropic animals due to human-environment interactions (MALTA \& LUPPI, 2007). The occurrence of different vector-borne pathogens (VBPs) has been reported in Didelphis sp. (MESSICK et al., 2002; CASTELLAW et al., 2011; MELO et al., 2016; SILVA et al., 2017; FERREIRA et al., 2017; LONDOÑO et al., 2017; SOARES et al., 2017). 'Candidatus Mycoplasma haemodidelphis' has been solely detected in the North American opossum (Didelphis virginiana) (MESSICK et al., 2000; MESSICK et al., 2002). In Brazil, although Didelphis sp. may be exposed to different VBPs, such as Ehrlichia spp., Rickettsia spp. and Borrelia spp. (MELO et al., 2016), to date only one opossum has been studied in this country and tested negative for hemotropic Mycoplasma spp. (SOUSA et al., 2017). Accordingly, the present study aimed to identify the occurrence of hemoplasma species in free-ranging opossums (D. albiventris) from Maringá city, Paraná State, southern Brazil, using PCR-based assays.

This study was approved by the Ethics Committee for Animal Experimentation and Animal Welfare at the Universidade Federal do Paraná, Brazil (protocol number 053/2018). Animal and laboratory procedures were approved and performed under regulations of the Chico Mendes Institute for Biodiversity Conservation (ICMBio, protocol number 63433-2).

The study was carried out in an urban public park of Maringá city: Ingá park ( $\left.51^{\circ} 55^{\prime} 59^{\prime \prime} \mathrm{W}, 23^{\circ} 25^{\prime} 28^{\prime \prime} \mathrm{S}\right)$. Maringá city is located in northwest region of Paraná State, which is characterized by semideciduous Atlantic Forest fragments and has a subtropical climate with an average temperature of $21.7^{\circ} \mathrm{C}$. The area has a diverse fauna, with populations of common marmoset (Callithrix jacchus), capybaras, and marsupials, as well as a wide variety of birds and fishes. $D$. albiventris is the only species of the genus Didelphis living in the park.

A total of eight adult (five females and three males) white-eared opossums ( $D$. albiventris) were captured using wire mesh traps baited with fruit. Opossums were identified at species level based on morphological and phenotypical characteristics (LEMOS \& CERQUEIRA, 2002). After chemical restraint (xylazine $4.0 \mathrm{mg} / \mathrm{kg}$ and ketamine $20 \mathrm{mg} / \mathrm{kg}$ ), animals were individually microchipped with a subcutaneous implant (Animall TAG ${ }^{\circledR}$, São Carlos, São
Paulo, Brazil) and visually inspected for ectoparasites (ticks and fleas). Ticks were removed and stored in 70\% ethanol-labeled tubes for further classification according to morphological taxonomic keys (ARAGÃO \& FONSECA, 1961; GUIMARÁES et al., 2001; MARTINS et al., 2016). Thereafter, EDTA blood samples were collected by caudal venipuncture and stored at $-20{ }^{\circ} \mathrm{C}$ until molecular analysis. After sampling, animals were monitored until total recovery from the chemical restraint and were then released at the park.

DNA was extracted from $200 \mu \mathrm{L}$ blood using a commercially available kit (Illustra ${ }^{\text {TM }}$ Blood Genomic Prep Mini Spin Kit, GE Healthcare Life Sciences, Little Chalfont, UK), according to the manufacturer's instructions. Ultrapure water was used as a negative control in parallel to monitor for cross-contamination.

To ensure successful DNA extraction, PCR for the opossum housekeeping gene glyceraldehyde-3-phosphate dehydrogenase (gapdh) (BIRKENHEUER et al., 2003) was performed in all samples. Thereafter, samples were screened using conventional PCR with genus-specific primers targeting a portion of the $16 \mathrm{~S}$ rRNA gene of Mycoplasma spp. (HOELZLE et al., 2011; MACHADO et al., 2017). The amplified PCR products were subjected to gel electrophoresis in $1.5 \%$ agarose gels for $1 \mathrm{~h}$ at $100 \mathrm{~V}$, followed by SYBR safe staining $\left(6 \mu \mathrm{g} / \mathrm{ml}\right.$; SYBR ${ }^{\circledR}$ Safe DNA Gel Stain, Invitrogen, CA, USA) and were viewed under a $312 \mathrm{~nm}$ UV light transilluminator.

Amplicons (871 bp) obtained from two Mycoplasma sp.-positive samples were purified from the agarose gel (Wizard ${ }^{\circledR}$ SV Gel and PCR Clean-Up System, Promega, Madison, EUA), evaluated by spectrophotometry for concentration and purity (NanodropTM 2000 Spectrophotometer, Thermo Fisher Scientific, Wilmington, MA, USA), and sequenced in both directions by the Sanger method. The assembled partial sequences of the $16 \mathrm{~S}$ rRNA gene were subjected to BLASTn analysis (ALTSCHUL et al., 1990) to determine the identity with sequences deposited in the GenBank database. Nucleotide sequences of the Mycoplasma sp. amplified herein were submitted to the GenBank database (accession numbers: MH158514 and MH158515).

The hemoplasma 16S rRNA sequences were aligned using MAFFT 7.110 (KATOH \& STANDLEY, 2013). The best-fit evolutionary model was estimated as $\mathrm{F} 81+\mathrm{G}$ using jModeltest 2.1.4 (DARRIBA et al., 2012). The Bayesian information criterion (BIC) and maximum likelihood (ML) algorithms were used for phylogenetic inference. Reconstruction was visualized with FigTree 1.4 .2 software.

All samples consistently amplified the opossum gapdh gene. Seven out of eight (87.50\%; CI 95\%: 47.35-99.68\%) opossums were positive for Mycoplasma sp. by PCR. Sequencing of the $16 \mathrm{~S}$ rRNA fragment showed $98.97 \%$ identity with ' $C a$. M. haemodidelphis' (GenBank ${ }^{\circledR}$ accession No: AF178676) detected in the USA. Phylogenetic 16S rRNA gene fragment analysis confirmed the close relationship of the white-eared opossum hemoplasma genotype with ' $C a$. M. haemodidelphis' detected in North American opossum. Moreover, the Mycoplasma sp. detected herein and the ' $\mathrm{Ca}$. M. haemodidelphis' detected in North American opossum formed a strongly supported branch with the hemotropic Mycoplasma sp. detected in raccoon (Procyon lotor) in the USA within the Mycoplasma suis group (Figure 1). 


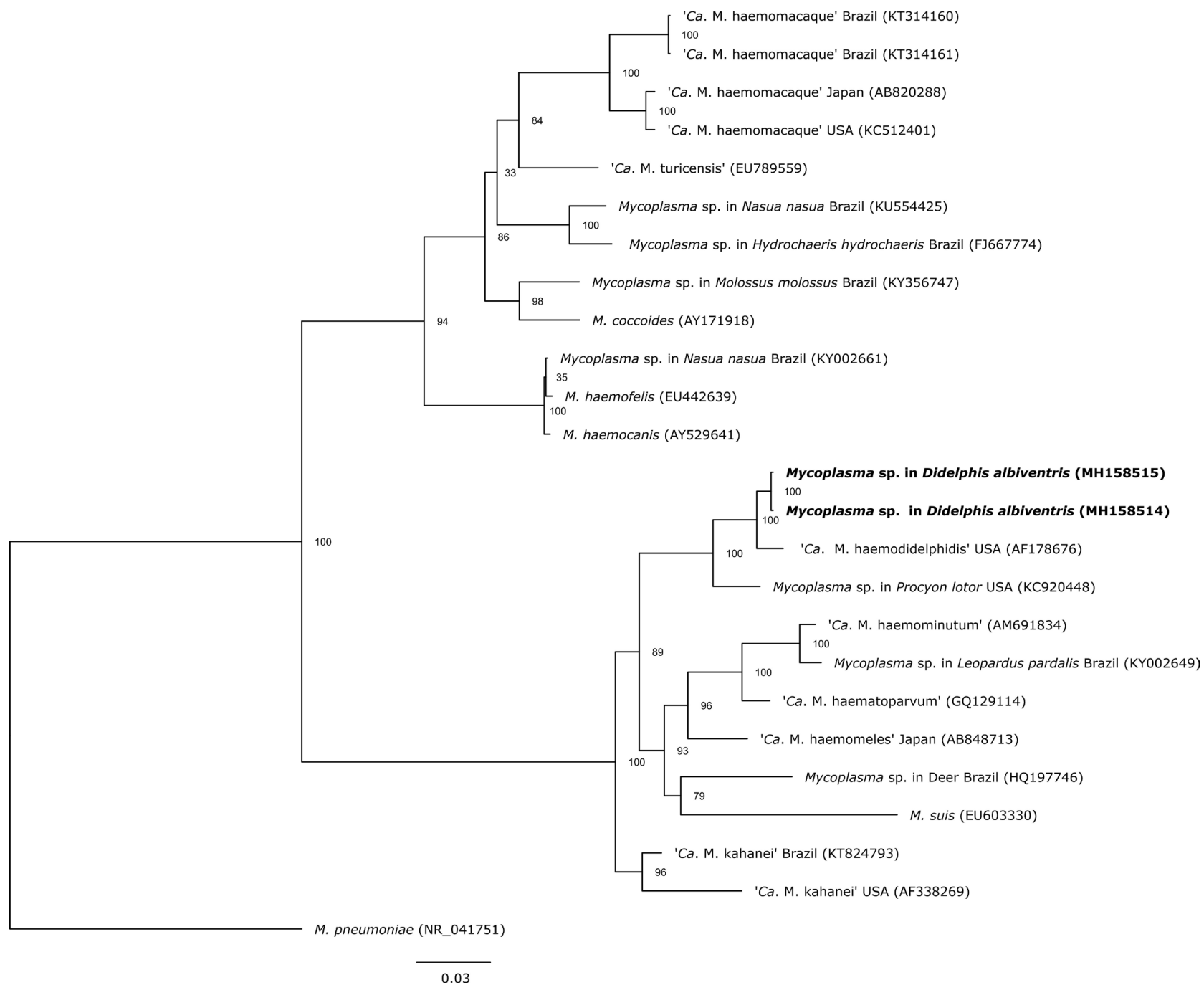

Figure 1. Phylogenetic tree based on partial sequences of the 16S rRNA gene, showing the relationship between the hemotropic Mycoplasma sp. detected in the white-eared opossums (Didelphis albiventris) from this study and other hemoplasmas. Bacillus subtilis was used as an outgroup. The GenBank accession number is in parentheses after the species name and origin of each bacterium. maximum likelihood analyses were carried out applying the F81+G model and 1000 bootstrap replicates for all analyses.

Three out of eight (37.50\%; CI 95\%: 8.52-75.51\%) opossums were infested by ticks ( 6 nymphs and 14 larvae) identified as Amblyomma dubitatum nymphs and Amblyomma sp. larvae.

Herein, we report the molecular detection of hemotropic Mycoplasma sp. closely related to ' $\mathrm{Ca}$. M. haemodidelphis' in free-ranging opossums from Brazil. To the authors' knowledge, molecular detection of hemoplasma in opossums (Didelphis sp.) has only been described in the United States (MESSICK et al., 2000; MESSICK, 2004). In the Brazilian Pantanal region, a previous study screened 30 marsupials for hemoplasma infection, including one white-eared opossum, and all tested negative for Mycoplasma sp. by conventional PCR targeting the 16S rRNA of these bacteria (SOUSA et al., 2017).

In the present study, $87.5 \%$ of opossums were positive for hemotropic Mycoplasma sp. Previous studies have suggested high hemoplasma prevalence rates in tropical regions, which may favor transmission by arthropod vectors. Although previous studies have implicated ticks in the transmission of hemoplasmas, such as Rhipicephalus sanguineus sensu lato as a vector of Mycoplasma haemocanis in dogs (SENEVIRATNA et al., 1973) and Haemaphysalis plumbeum and Rhipicephalus bursa as vectors of Mycoplasma ovis in small ruminants (NEIMARK et al., 2004), to date there has not been adequate evidence to support the contention that hemoplasmas are truly vector-borne pathogens. Herein, although 37\% of opossums were infested by $A$. dubitatum and Amblyomma sp. ticks, further studies are needed to elucidate the role of $A$. dubitatum ticks in the transmission of hemoplasmas.

Raccoons are considered adapted to urbanized and suburbanized environments (GEHRT et al., 2010), similar to opossums. A previous study has shown that raccoons from undisturbed habitats were more likely to be infected by hemoplasmas than animals from urban areas (VOLOKHOV et al., 2017). Herein, a high prevalence of hemotropic Mycoplasma sp. was found in opossums from public parks located in an urban area of Paraná State, southern Brazil. 
Further studies are needed to elucidate differences in hemoplasma prevalence among environments.

Additionally, the analyses of the partial sequence of $16 \mathrm{~S}$ rRNA gene have identified a potentially novel hemoplasma species infecting white-eared opossums from Southern Brazil. This data is supported since the inhabited areas for $D$. virginiana and $D$. albiventris do not overlap (COSTA et al., 2015; PÉREZ-HERNANDEZ et al., 2016), and thus, an infection of $D$. albiventris in Brazil with ' $C a$. M. haemodidelphis' from $D$. virginiana by direct transmission is less likely. Further studies evaluating other housekeeping genes (e.g. $r p o B, 23 \mathrm{~S}$ rRNA) are needed for characterization of this potentially novel hemotropic Mycoplasma species.

A potentially novel hemotropic Mycoplasma sp. is very prevalent in white-eared opossums from southern Brazil. This is the first report on detection of a hemotropic Mycoplasma sp. infecting opossums from South America.

\section{Acknowledgements}

This study is part of a $\mathrm{PhD}$ degree for Paula Massini at the Universidade Estadual de Londrina. Dr. Mongruel and Dr. Valente were sponsored by a fellowship from the Brazilian National Council of Scientific and Technological Development (CNPq) at the time of research. CNPq also provided a Research Productivity scholarship to Dr. Rafael Vieira.

\section{References}

Altschul SF, Gish W, Miller W, Myers EW, Lipman DJ. Basic local alignment search tool. J Mol Biol 1990; 215(3): 403-410. http://dx.doi. org/10.1016/S0022-2836(05)80360-2. PMid:2231712.

André MR, Adania CH, Allegretti SM, Machado RZ. Hemoplasmas in wild canids and felids in Brazil. J Zoo Wildl Med 2011; 42(2): 342-347. http://dx.doi.org/10.1638/2010-0198.1. PMid:22946419.

Aragão H, Fonseca F. Notas de ixodologia: VIII. Lista e chave para os representantes da fauna ixodológica brasileira: notas de ixolodologia. Mem Inst Oswaldo Cruz 1961; 59(2): 115-129. http://dx.doi.org/10.1590/ S0074-02761961000200001. PMid:13861962.

Birkenheuer AJ, Levy MG, Breitschwerdt EB. Development and evaluation of a seminested PCR for detection and differentiation of Babesia gibsoni (Asian genotype) and B. canis DNA in canine blood samples. J Clin Microbiol 2003; 41(9): 4172-4177. http://dx.doi.org/10.1128/ JCM.41.9.4172-4177.2003. PMid:12958243.

Bonato L, Figueiredo MAP, Gonçalves LR, Machado RZ, André MR. Occurrence and molecular characterization of Bartonella spp. and hemoplasmas in neotropical primates from Brazilian Amazon. Comp Immunol Microbiol Infect Dis 2015; 42: 15-20. http://dx.doi.org/10.1016/j. cimid.2015.09.001. PMid:26577193.

Castellaw AH, Chenney EF, Varela-Stokes AS. Tick-borne disease agents in various wildlife from Mississippi. Vector Borne Zoonotic Dis 2011; 11(4): 439-442. http://dx.doi.org/10.1089/vbz.2009.0221. PMid:20846016.

Costa LP, Astua de Moraes D, Brito D, Soriano P, Lew D. Didelphis albiventris. Cambridge: The IUCN Red List of Threatened Species; 2015. http://dx.doi.org/10.2305/IUCN.UK.2015-4.RLTS.T40489A22176404.en.
Cubilla MP, Santos LC, Moraes W, Cubas ZS, Leutenegger CM, Estrada $\mathrm{M}$, et al. Microscopic and molecular identification of hemotropic mycoplasmas in South American coatis (Nasua nasua). Comp Immunol Microbiol Infect Dis 2017a; 53: 19-25. http://dx.doi.org/10.1016/j. cimid.2017.06.004. PMid:28750863.

Cubilla MP, Santos LC, Moraes W, Cubas ZS, Leutenegger CM, Estrada $\mathrm{M}$, et al. Occurrence of hemotropic mycoplasmas in non-human primates (Alouatta caraya, Sapajus nigritus and Callithrix jacchus) of southern Brazil. Comp Immunol Microbiol Infect Dis 2017b; 52: 6-13. http://dx.doi. org/10.1016/j.cimid.2017.05.002. PMid:28673463.

Darriba D, Taboada GL, Doallo R, Posada D. jModelTest 2: more models, new heuristics and parallel computing. Nat Methods 2012; 9(8): 772 http://dx.doi.org/10.1038/nmeth.2109. PMid:22847109.

de Sousa KCM, Herrera HM, Secato CT, Oliveira AV, Santos FM, Rocha FL, et al. Occurrence and molecular characterization of hemoplasmas in domestic dogs and wild mammals in a Brazilian wetland. Acta Trop 2017; 171: 172-181. http://dx.doi.org/10.1016/j.actatropica.2017.03.030. PMid:28366511.

Dias GB, Amaral RB, Gatto IRH, Lapera IM, Oliveira LG, Hoppe EGL, et al. Molecular detection of Mycoplasma suis in captive whitelipped peccaries (Tayassu pecari) and wild boars (Sus scrofa) in Brazil. Comp Immunol Microbiol Infect Dis 2019; 63: 94-96. http://dx.doi. org/10.1016/j.cimid.2019.01.013. PMid:30961824.

Ferreira JIGS, Costa AP, Nunes PH, Ramirez D, Fournier GFR, Saraiva D, et al. New Trypanosoma species, Trypanosoma gennarii sp. nov., from South American marsupial in Brazilian Cerrado. Acta Trop 2017; 176: 249-255. http://dx.doi.org/10.1016/j.actatropica.2017.08.018. PMid:28847674.

Furtado MM, Taniwaki SA, Metzger B, O’Dwyer LH, Paduan KDS, Jácomo ATA, et al. First detection of feline hemoplasmas in free-ranging jaguars (Panthera onca). Vet Microbiol 2018; 214: 75-80. http://dx.doi. org/10.1016/j.vetmic.2017.12.009. PMid:29408036.

Gehrt SD, Riley SPD, Cypher BL. Urban Carnivores: Ecology, conflict, and conservation. Baltimore: The Johns Hopkins University Press; 2010.

Gonçalves LR, Roque ALR, Matos CA, Fernandes SJ, Olmos IDF, Machado RZ, et al. Diversity and molecular characterization of novel hemoplasmas infecting wild rodents from different Brazilian biomes. Comp Immunol Microbiol Infect Dis 2015; 43: 50-56. http://dx.doi. org/10.1016/j.cimid.2015.10.006. PMid:26616660.

Guimaraes AMS, Javorouski ML, Bonat M, Lacerda O, Balbinotti B, Queiroz LGPB, et al. Molecular detection of 'Candidatus Mycoplasma haemominutum' in a lion (Panthera leo) from a brazilian zoological garden. Rev Inst Med Trop São Paulo 2007; 49(3): 195-196. http://dx.doi. org/10.1590/S0036-46652007000300011. PMid:17625699.

Guimarães JH, Tucci EC, Barros-Battesti DM. Ectoparasitos de importância veterinária. São Paulo: Plêiade; 2001.

Hoelzle K, Winkler M, Kramer MM, Wittenbrink MM, Dieckmann SM, Hoelzle LE. Detection of Candidatus Mycoplasma haemobos in cattle with anaemia. Vet J2011; 187(3): 408-410. http://dx.doi.org/10.1016/j. tvjl.2010.01.016. PMid:20188610.

Ikeda P, Seki MC, Carrasco AOT, Rudiak LV, Miranda JMD, Gonçalves SMM, et al. Evidence and molecular characterization of Bartonella spp. and hemoplasmas in neotropical bats in Brazil. Epidemiol Infect 2017 145(10): 2038-2052. http://dx.doi.org/10.1017/S0950268817000966. PMid:28502279. 
Katoh K, Standley DM. MAFFT Multiple Sequence Alignment Software Version 7: Improvements in performance and usability. Mol Biol Evol 2013; 30(4): 772-780. http://dx.doi.org/10.1093/molbev/mst010. PMid:23329690.

Lemos B, Cerqueira R. Morphological differentiation in the white-eared opossum group (Didelphidae: didelphis). J Mammal 2002; 83(2): 354369. http://dx.doi.org/10.1644/1545-1542(2002)083<0354:MDITW $\mathrm{E}>2.0 . \mathrm{CO} ; 2$.

Londoño AF, Acevedo-Gutiérrez LY, Marín D, Contreras V, Díaz FJ, Valbuena G, et al. Wild and domestic animals likely involved in rickettsial endemic zones of Northwestern Colombia. Ticks Tick Borne Dis 2017; 8(6): 887-894. http://dx.doi.org/10.1016/j.ttbdis.2017.07.007. PMid:28774495.

Machado CAL, Vidotto O, Conrado FO, Santos NJR, Valente JDM, Barbosa IC, et al. Mycoplasma ovis infection in goat farms from northeastern Brazil. Comp Immunol Microbiol Infect Dis 2017; 55: 1-5. http://dx.doi. org/10.1016/j.cimid.2017.08.004. PMid:29127988.

Malta MCC, Luppi MM. Marsupilia - Didelphimorphia (Gambá, Cuíca). In: Cubas ZS, Silva JCR, Catão-Dias JL. Tratado de animais selvagens. São Paulo: Rocca; 2007. p. 340-347.

Martins TF, Barbieri ARM, Costa FB, Terassini FA, Camargo LMA, Peterka CRL, et al. Geographical distribution of Amblyomma cajennense (sensu lato) ticks (Parasitiformes: Ixodidae) in Brazil, with description of the nymph of $A$. cajennense (sensu stricto). Parasit Vectors 2016; 9(186):114. http://dx.doi.org/10.1186/s13071-016-1460-2. PMid:27036324.

Melo ALT, Aguiar DM, Spolidorio MG, Yoshinari NH, Matushima ER, Labruna MB, et al. Serological evidence of exposure to tick-borne agents in opossums (Didelphis spp.) in the state of São Paulo, Brazil. Rev Bras Parasitol Vet 2016; 25(3): 348-352. http://dx.doi.org/10.1590/S198429612016028. PMid:27276663.

Melo CMF, Daneze ER, Mendes NS, Souza Ramos IA, Morales-Donoso JA, Fernandes SJ, et al. Genetic diversity and hematological and biochemical alterations in Alouatta primates naturally infected with hemoplasmas in Brazil. Comp Immunol Microbiol Infect Dis 2019; 63: 104-111. http:// dx.doi.org/10.1016/j.cimid.2019.01.011. PMid:30961804.

Messick JB, Berent LM, Ehrhart EJ, Wasmer CC. Light and electron microscopic features of eperythrozoon-like parasites in a North American opossum (Didelphis virginiana). J Zoo Wildl Med 2000; 31(2): 240-243. http://dx.doi.org/10.1638/1042-7260(2000)031[0240:LAEMFO]2.0. CO;2. PMid:10982141.

Messick JB, Walker PG, Raphael W, Berent L, Shi X. 'Candidatus mycoplasma haemodidelphidis' sp. nov., 'Candidatus mycoplasma haemolamae' sp. nov. and Mycoplasma haemocanis comb. nov., haemotrophic parasites from a naturally infected opossum (Didelphis virginiana), alpaca (Lama pacos) and $\operatorname{dog}$ (Canis familiaris): phylogenetic and secondary structural relatedness of their 16S rRNA genes to other mycoplasmas. Int J Syst Evol Microbiol 2002; 52(Pt 3): 693-698. http://dx.doi.org/10.1099/0020771352-3-693. PMid:12054227.

Messick JB. Hemotrophic mycoplasmas (hemoplasmas): a review and new insights into pathogenic potential. Vet Clin Pathol 2004; 33(1): 2-13. http://dx.doi.org/10.1111/j.1939-165X.2004.tb00342.x. PMid:15048620.

Neimark H, Hoff B, Ganter M. Mycoplasma ovis comb. nov. (formely Eperythrozoon ovis), an epierythrocytic agent of haemolytic anaemia in sheep and goats. Int J Syst Evol Microbiol 2004; 54(Pt 2): 365-371. http:// dx.doi.org/10.1099/ijs.0.02858-0. PMid:15023944.

Pérez-Hernandez R, Lew D, Solari S. Didelphis virginiana. Cambridge: The IUCN Red List of Threatened Species; 2016.

Ramalho AC, Guerra RR, Mongruel ACB, Vidotto O, Lucena RB, Guerra MVSF, et al. Mycoplasma sp. infection in captive Marcgrave's capuchin monkeys (Sapajus flavius). Comp Immunol Microbiol Infect Dis 2017; 51: 34-36. http://dx.doi.org/10.1016/j.cimid.2017.03.003. PMid:28504092.

Seneviratna P, Weerasinghe N, Ariyadasa S. Transmission of Haemobartonella canis by the dog tick, Rhipicephalus sanguineus. Res Vet Sci 1973; 14(1): 112114. http://dx.doi.org/10.1016/S0034-5288(18)33950-X. PMid:4736045.

Silva MRL, Fornazari F, Demoner LC, Teixeira CR, Langoni H, O’Dwyer LH. Didelphis albiventris naturally infected with Hepatozoon canis in southeastern Brazil. Ticks Tick Borne Dis 2017; 8(6): 878-881. http:// dx.doi.org/10.1016/j.ttbdis.2017.07.005. PMid:28728938.

Soares HS, Marcili A, Barbieri ARM, Minervino AHH, Moreira TR, Gennari SM, et al. Novel piroplasmid and Hepatozoon organisms infecting the wildlife of two regions of the Brazilian Amazon. Int $J$ Parasitol Parasites Wildl 2017; 6(2): 115-121. http://dx.doi.org/10.1016/j. ijppaw.2017.05.002. PMid:28603688.

Sykes JE, Lindsay LL, Maggi RG, Breitschwerdt EB. Human coinfection with Bartonella henselae and two hemotropic mycoplasma variants resembling Mycoplasma ovis. J Clin Microbiol 2010; 48(10): 3782-3785. http://dx.doi.org/10.1128/JCM.01029-10. PMid:20702675.

Vieira RFC, Molento MB, Santos LC, Moraes W, Cubas ZS, Santos AP, et al. Detection of a novel hemoplasma based on 16S rRNA gene DNA in captive and free-ranging capybaras (Hydrochaeris hydrochaeris). Vet Microbiol 2009; 139(3-4): 410-413. http://dx.doi.org/10.1016/j. vetmic.2009.06.018. PMid:19592180.

Volokhov DV, Hwang J, Chizhikov VE, Danaceau H, Gottdenker NL. Prevalence, genotype richness, and coinfection patterns of Hemotropic Mycoplasmas in Raccoons (Procyon lotor) on environmentally protected and urbanized Barrier Islands. Appl Environ Microbiol 2017; 83(9): e00211-e00217. http://dx.doi.org/10.1128/AEM.00211-17. PMid:28258139. 